«Системні технології» 3 (128) 2020 «System technologies»

DOI 10.34185/1562-9945-3-128-2020-02

УДК 681.03

І.Н. Вдовиченко

\title{
ФОРМУВАННЯ ГРУП ДЛЯ ВИКОРИСТАННЯ МЕТОДУ ВЗАЕМНОГО НАВЧАННЯ
}

В статті представлено метод взаємного навчання. Розглянуто показники, які впливають на формування груп. Представлені результати експерименту по формуванню схем взаємодії студентів в бригадах взаємонавчання. Для правильного підбору студентів в групи запропоновано соціометричний метод.

Ключові слова: метод взаємного навчання, студенти, навчальний процес, дослідження, сочіометричний метод.

Постановка проблеми. Дослідження та впровадження методу взаємного навчання може стати одним із шляхів підвищення ефективності підготовки спеціалістів. Хороший фахівець характеризується не тільки знанням, але і вмінням самостійно поповнювати їх, відповідати сучасним потребам виробництва. Для цього потрібно орієнтуватися в швидкому потоці наукової інформації. Всі ці якості не можна сформувати у сучасного фахівця, орієнтуючись тільки на однотипні та звичні форми і методи навчання. Необхідно розробляти і впроваджувати інші форми і методи, які б стимулювали допитливість та відповідали вимогам життя.

Спосіб взаємного навчання може внести свій вагомий вклад в рішення цих задач. Взаємним навчанням називається така форма організації навчального процесу, при якій деякі функції викладача виконуються самими студентами. Спосіб дає можливість варіювати кількість тих, хто навчає і тих, хто навчається. Така форма навчання дає можливість працювати колективно, при цьому формує самостійність мислення, розвиває мову, знімає напругу, розвиває індивідуальні здібності студентів, одночасно підвищуючи якість знань та умінь.

(C) Вдовиченко I.H., 2020 
«Системні технології» 3 (128) 2020 «System technologies»

Аналіз останніх досліджень і публікацій. Ідея взаємного навчання захоплювала педагогів упродовж усієї історії педагогіки. Тому це не нова методика, але її невиправдано “забували”. Офіційне ж визнання і поширення вона отримала у кінці 18 і початку 19 віків, коли англійські педагоги Белл Андру і Ланкастер Джозеф створили школи і розробили систему взаємного навчання. Чіткий розподіл обов'язків, строго певний порядок дій студентів, висока оперативність системи підведення підсумків, визначення місця кожному студентові відповідно до його результатів, розумне чергування видів діяльності - ось основні заходи, що дозволяють створювати високу зацікавленість і успішно управляти процесом навчання великої кількості студентів. Така організація учбового процесу дозволяла істотно підвищити ефективність навчання [1]. Добре відома технологія колективного взаємонавчання А.Г. Ривіна.

Протягом останніх десятиліть використовуються колективні способи навчання, що втілили досвід українських педагогів - В.К. Дяченко та О.Г. Ривіна. Розроблено декілька варіантів методики взаємного навчання. Значний внесок у розробку загальних принципів організації групової та колективної роботи дали дослідження В.В. Котової, Г.О. Цукерман, О.Г. Ярошенко та інших. Ідеї взаємонавчання отримують все більше розповсюдження у системах навчання різних країн світу, тому що відкривають можливості для співпраці, спілкування, сприяють досягненню вищих результатів засвоєння знань і вмінь. Багато уваги цьому питанню присвячує С.О. Карплюк.

Мета дослідження. Приділяючи увагу методичному матеріалу, тематиці завдань, посібникам для взаємного навчання і перехресним програмам, учбовому діалогу, взаємному аналізу відповідей та дій, обговоренню завдань, на наш погляд, незаслужено мало уваги приділяється способу формування робочих груп для взаємонавчання. Допускається, мабуть, що це відбудеться інтуїтивно. Але нажаль, це не так. Як відомо, від правильного формування робочих груп залежить їх продуктивність, швидкість та якість роботи. Так само і в навчанні. Дослідити залежності успіху навчання від різних способів формування груп, на нашу думку, назріла проблема. 
«Системні технології» 3 (128) 2020 «System technologies»

\section{Викладення основного матеріалу дослідження. При} формуванні студентських груп для взаємонавчання, крім успішності і здібностей студентів, необхідно враховувати i ïx психологічну сумісність, темп засвоєння матеріалу, темперамент ін. Для дослідження впливу способу формування робочих груп на результати взаємонавчання проводили наступний експеримент. Частково скористаємося результатами дослідження, яке було нами проведено для підтвердження переваг цього методу навчання. У роботі [1] запропоновано наступний спосіб формування групбригад для роботи методом взаємонавчання. Групу студентів третього курсу, спеціальності "Гнучкі комп'ютеризовані системи і робототехника" розділили на дві підгрупи. Перша підгрупа вивчала дисципліну за звичайною методикою. Студенти, прослухавши лекційний матеріал, індивідуально виконували лабораторні роботи. Друга підгрупа була розбита на чотири бригади, в кожній з яких були три студенти. Дві бригади сформували по такій структурі: один "сильний" студент, один "середній" студент і один "слабкий" студент. А наступні дві бригади сформували по такій структурі: один "сильний" студент і два "слабких" студента.

Як і очікувалося, бригади першої структури (один "сильний", один "середній" і один "слабкий" студент) по швидкості вивчення матеріалу показували кращі результати. Це пояснюється тем, що вони краще підготовлені ("сильний" та "середній" студенти), та ще й тим, що могли діяти за різними схемами: №1 или №2 или №3.

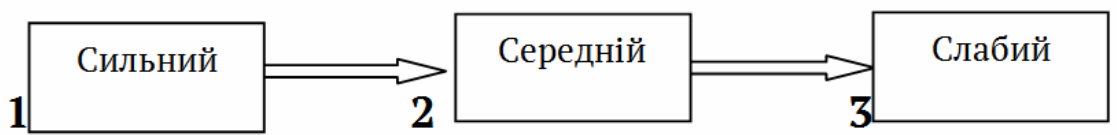

Рисунок1 - Схема №1

Перший роз’яснює другому, а другий роз’яснює третьому. 
«Системні технології» 3 (128) 2020 «System technologies»

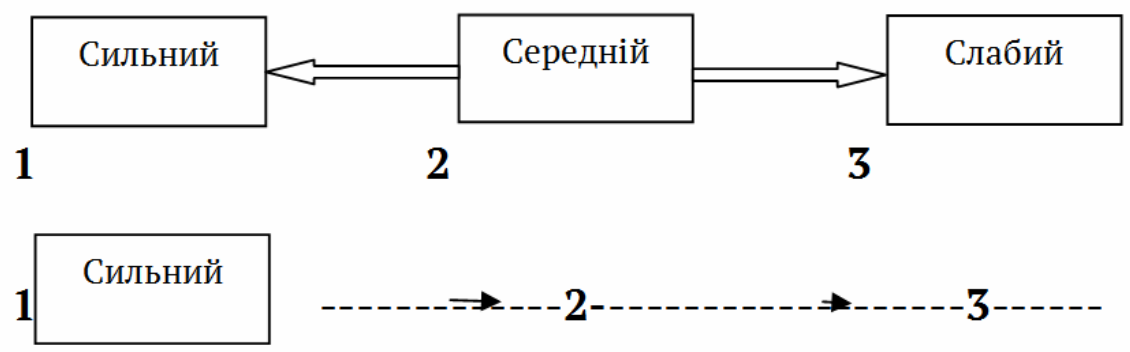

Рисунок 2 - Схема №2

Другий роз'яснює першому і третьому, потім перший доповнює для другого і третього.

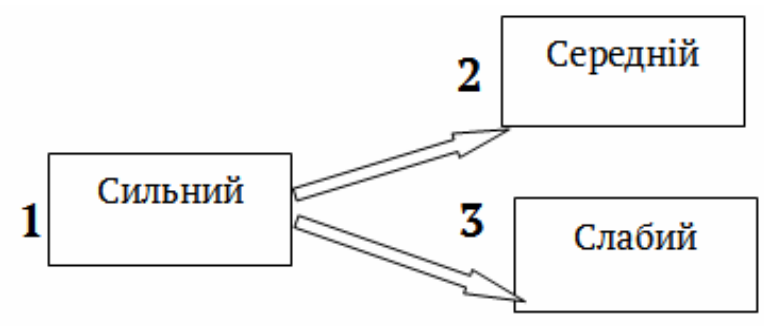

Рисунок 3- Схема №3

Перший роз'яснює другому і третьому. Схема, коли роз'яснює третій не працює.

Бригади другої структури (один "сильний" i два "слабких" студента) можуть навчатися тільки по одній схемі.

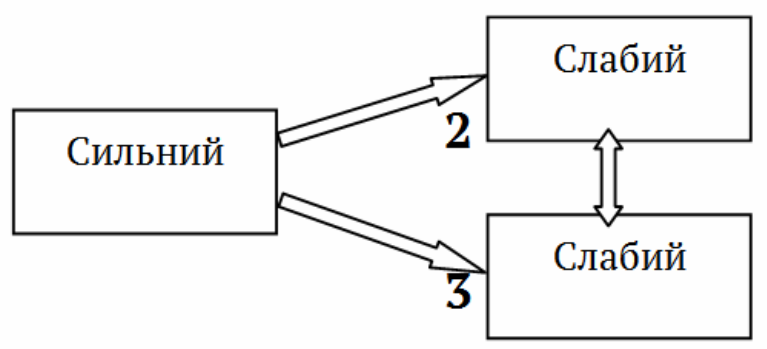

Рисунок 4 - Схема №4

Перший роз'яснює другому і третьому, при потребі другий і третій уточнюють один одному.

Схема, коли роз'яснює третій чи другий не працює. Загальна підготовка в них нижча. Тому бригади другої структури повільніше вивча16 
«Системні технології» 3 (128) 2020 «System technologies»

ють матеріал. Кожна з схем має свої переваги та недоліки. Вибір представлених структур бригад залежить тільки від успішності студентів в групі. Крім розглянутих, можливо сформувати і інші структури. Наприклад: всі "середні" студенти, два "середніх" і один "слабких" і т.п.

Але, як вказувалося раніше, необхідно враховувати і їх психологічну сумісність. Студентська бригада для взаємонавчання: "є полиергатичною системою, якість функціонування якої визначається характеристиками не тільки окремих операторів, але і колективу як цілого. Якість функціонування залежить від безлічі факторів, таких як злагодженість колективу, сумісність його членів, структура зв'язків у колективі, розподіл функцій і так далі”[2].

При аналізі результатів навчання методом взаємонавчання з'являється проблема оцінки діяльності студентів в бригаді. Позитивний результат багато в чому залежить від правильності розподілу ролей між членами бригади студентів, від того наскільки неформальна структура бригади збігається з формальною.

Для врахування цих факторів, найбільш оптимальний варіант скористатися соціометричним методом. Соціометричний метод $є$ найбільш ефективним способом групової оцінки кожного кандидата в бригаду. Як і кожен метод, він має сильні і слабкі сторони. Позитивним $\epsilon$ те, що соціометричні дослідження дають результати у формі кількісних індексів у сфері, що вважалася традиційно не формалізуємою і придатний для малих груп (до 40 осіб.)

До позитивних моментів, що цікавлять нас, також відноситься можливість застосування системно-структурного аналізу та моделювання, можливість за короткий час зібрати значний за обсягом матеріал.

Соціометричний метод полягає в наступному: членам підгрупи пропонуються питання, для визначення їх взаємин і оцінок їх якостей. В результаті визначаємо хотіли, або не хотіли б вони займатися в одній бригаді з конкретним студентом. За підсумками соціометричного опитування складається матриця, в вертикальні стовпці якої поміщають 
«Системні технології» 3 (128) 2020 «System technologies»

прізвища (номера) тих, «хто вибрав», а в горизонтальні рядки - тих, «кого вибрали».

Значення +1 означає позитивний вибір, - 1 - негативний вибір, 0 - відсутність вибору. Результати у таблиці 1. У підсумку по стовпцю отримаємо сумарну картину для конкретного студента. По таблиці 1 можна порахувати узагальнений соціометричний показник. Якщо він позитивний і високий, то вважається, що в групі хороша психологічна сумісність. У нашому випадку він дорівнює 31.

За результатом опитування підгрупи студентів складаємо матрицю $\mathrm{X}$, аналогічно таблиці 1 , але в осередках змінна $x_{i j}$, дорівнює:

$$
x_{i j}=\left\{\begin{array}{l}
1, \text { якщуо } j-\check{u} \text { студент обрав } i-2 о \text { студента, } \\
0, \text { якщуо } j-\check{u} \text { студент не обрав } i-\text { го студента. }
\end{array}\right.
$$

Таблиця 1

\begin{tabular}{|c|c|c|c|c|c|c|c|c|c|c|c|c|}
\hline & 1 & 2 & 3 & 4 & 5 & 6 & 7 & 8 & 9 & 10 & 11 & 12 \\
\hline 1 & & 1 & 1 & 0 & -1 & -1 & 1 & -1 & 0 & 0 & 1 & 1 \\
\hline 2 & 1 & & 0 & 1 & -1 & 0 & 1 & -1 & -1 & 0 & 1 & 0 \\
\hline 3 & 0 & 0 & & 1 & 0 & 0 & 0 & 1 & -1 & 1 & 1 & 0 \\
\hline 4 & 1 & 0 & 0 & & 0 & 1 & 1 & 0 & 0 & 0 & 0 & 1 \\
\hline 5 & 0 & 1 & 0 & 0 & & 0 & 1 & 1 & 1 & 1 & 0 & -1 \\
\hline 6 & 0 & 1 & 1 & 1 & 1 & & 0 & -1 & 0 & 0 & -1 & 1 \\
\hline 7 & -1 & 0 & 1 & 0 & 0 & -1 & & 1 & 0 & -1 & 0 & 0 \\
\hline 8 & 1 & 1 & 0 & 0 & -1 & 0 & 0 & & 0 & 1 & -1 & 1 \\
\hline 9 & 0 & 1 & 1 & 1 & 1 & -1 & 0 & 0 & & 0 & 0 & 0 \\
\hline 10 & 0 & 0 & 1 & 0 & -1 & -1 & 1 & 0 & 1 & & 1 & 1 \\
\hline 11 & 0 & 0 & 0 & 0 & 0 & 1 & 0 & 0 & 1 & 1 & 1 & -1 \\
\hline 12 & 1 & 0 & -1 & -1 & 0 & -1 & 1 & 1 & 1 & 1 & 1 & 1 \\
\hline
\end{tabular}

Використовуючи алгоритм задачі про лідера, відносний коефіцієнт "дружелюбності" для кожного студента розраховується за формулою:

$$
K_{i}^{1}=\frac{\sum_{j=1}^{n} x_{i j}}{\sum_{i=1}^{n} \sum_{j=1}^{n} x_{i j}} \quad \mathrm{i}=1,2, \ldots \mathrm{n}
$$

де $\mathrm{n}$ - число студентів в групі; $x_{i j}$ - елементи матриці X;

У чисельнику сума одиниць (голосів) поданих за і - го студента ділиться на загальну суму одиниць. Чим більше коефіцієнт "дружелюбності" студента, тим більше він затребуваний в бригаді для взаємонавчання. 
«Системні технології» 3 (128) 2020 «System technologies»

Висновки. Як показав експеримент, бригади різної структури вимагають різного підходу. У них різні алгоритми навчання. Для правильного формування бригади можна використати соціометричний метод. Результат опитувань занести у спеціальну таблицю, обчислити узагальнений соціометричний показник. Якщо він низький, та ще й від’ємний, то від використання методу взаємонавчання для цієї групи, краще відмовитись. В такій групі дуже складно сформувати бригади 3 хорошою соціально-психологічною сумісністю членів. Зрозуміло, що результат навчання буде гіршим. Використовуючи таблицю 1, можна автоматизувати аналіз та вибір членів бригади, враховуючи хто кого вибрав. Правильно сформовані бригади забезпечать ефективне використання методу взаємонавчання.

\section{ЛІТЕРАТУРА / ЛИТЕРАТУРА}

1. Вдовиченко І.Н. Колективна наукова монографія «Сучасний педагог». - Дніпро: Акцент ПП, 2020. - 236с.

2. Стенин А.А. Автоматизированные обучающие системы (анализ и синтез). Научная монография. - Луганск: ВУНУ, 2000. -109с.

3. Баранник Н.С., Горбатюк В.Ф. Взаимное обучение как модификация парного обучения. /Н. Баранник, В. Горбатюк. // Фундаментальные исследования. 2012. № 6-2. С. 350-354.

\section{REFERENCES}

1. Vdovychenko I. N. Collective scientific monograph "Modern Teacher". Dnieper: Accent of state of emergency, 2020. - 236 pages.

2. Stenin A. A. The automated training systems (the analysis and synthesis). Scientific monograph. - Luhansk: VUNU, 2000. - 109 pages.

3. Barannik N.S., Gorbatyuk V. F. Mutual training as modification of pair training. /N. Barannik, V. Gorbatyuk. //Basic researches. 2012. No 6-2. Page 350354 .

Формирование групп для использования метода взаимного обучения

Представлен метод взаимного обучения. Обоснована целесообразность его внедрения. Отмечено, что способу формирования группы студентов для метода взаимного обучения уделяется мало внимания. Рассмотрены характерные показатели, которые влияют на формирование групп. В работе представлены результаты эксперимента по формированию схем взаимодействия студентов в бригадах взаимообучения. Для правильного подбора студентов в группы предложено использовать социометрический метод. 
«Системні технології» 3 (128) 2020 «System technologies»

\title{
Formation of the DLYA groups of use of a method of mutual training
}

Analysis of the last researches and publications. Within the last decades collective ways of training are used that embodied experience of the Ukrainian teachers - V.K. Dyachenko and O. G. of a ryvin. V.V. Kotova's researches, G.A. Zuckerman, O.G. Yaroshenko and others gave the significant contribution to development of the general principles of the organization of group and collective work. The ideas of mutually training gain more and more distribution at the systems of training of the different countries of the world because open opportunities for cooperation, communication, promote achievement of the highest results of assimilation of knowledge and abilities.

Research objective. Paying attention methodical material, subject of tasks, helpers for mutual training, educational dialogue, mutual the analysis of answers and actions, to discussion of tasks, in our opinion, unfairly not enough attention is paid an image formation of the working groups for mutually training. To investigate dependences of success of training on various ways of formation of groups, according to us, the problem ripened.

Statements of the main material of a research. Influence on student's groups for a mutual learning, except progress and abilities of students, it is necessary to consider also their psychological compatibility, rate of digestion of material, temperament other. Characteristic indicators which influence formation of groups are analysed.

For a research of influence of an image of formation of the working groups on results of mutually training made a scientific experiment. In work it is offered a way of formation of groups of crews. 2 schemes of formation of groups were offered. Each of schemes studied on different algorithms. For the correct selection of students in groups it is offered to use a sots_ometrichny method.

Conclusions. As showed an experiment, crews of various structure demand different approach. After calculation of the general sociometric indicator, it is possible to draw a conclusion about social and psychological compatibility of members of the group. Crews are correctly created will provide effective use of a method of mutually training.

Вдовиченко Ирина Никифоровна - доцент Криворожского национального университета.

\author{
Вдовиченко Ірина Никифорівна - доцент Криворізького національного \\ університету.
}

Vdovychenko Irina - associate professor of Kryvyi Rih National university. 